\title{
FINANCIAL ENGINEERING TO OPTIMIZE RISK MANAGEMENT IN BANKS BASED ON INTEREST RATE SWAPS TO BETTER HEDGE THE EXPOSURE TO INTEREST RATE FLUCTUATIONS THE CASE OF BANKS IN SYRIA
}

\author{
AKHMEDOV Fakhraddin N. ${ }^{1}$, ZEITOUN Mhd Shaker ${ }^{2}$, AL HUMSSI Ahmad ${ }^{3}$ \\ ${ }^{1}$ RUDN University, Moscow, (RUSSIA) \\ ${ }^{2} R U D N$ University, Moscow, (RUSSIA) \\ ${ }^{3}$ RUDN University, Moscow, (RUSSIA) \\ E-mails: akhmedov_fn@pfur.ru ; sh.zeitoun@live.com ;L6h88@mail.ru
}

\begin{abstract}
The banking system is affected by uncertainties related to the evolution of pandemic. One of the identified risks is that of a fluctuation of rates. Volatility of Interest rates is one of the major risks for the banking system. Therefore, financial engineering can be used as a very important hedging practice for banks against such a risk. The aim of this study is to develop a risk hedging mechanism to better overcome market volatility by hedging position against the exposure to interest rate risk based on credit derivatives. Therefore, this study uses Interest Rate Swaps (IRS)s to better hedge the exposure of banks to interest rate fluctuations in stress conditions giving consideration to the case study of banks in Syria in optimizing hedging practices based on Interest Rate Swaps. The aim is to use financial engineering to provide banks with a hedging technique to better absorb shocks in times of stress conditions. This has been discussed and illustrated with visual model diagrams. The case study of banks in Syria is not just the story of individual banks but a window into how to hedge the exposure of banks in stress conditions. In the end, most banking crises are quite similar. The recommendations set out in this study provide banks with an optimized hedging practice which is not part of current financial engineering at banks in Syria.

Keywords: Stress Conditions, Hedging, Interest Rate Risk, Derivatives, Interest Rate Swaps, Financial Engineering, Banks in Syria.
\end{abstract}

JEL:G32

DOI: $10.5937 /$ intrev2102101A

UDC: 005.334:336.71(569.1)

005.591.1:336.781.5

COBISS.SR-ID 43507721 


\section{INTRODUCTION}

Financial engineering presents an opportunity to any bank to hedge its exposure. With all the literatures on financial engineering in recent years, unfortunately, significant existing and new challenges remain to be addressed. This is because the emergence of new banking practices and new financial products created new exposures, and increased the impact and frequency of existing exposures. Existing hedging practices are not perfect. They can always be improved to accommodate the severity of the contemporary stress conditions in some markets around the world. Exposure to interest rate risk and interest rate fluctuations continues to be the one of the leading sources of problems in banks world-wide.

Interest rate risk occurs when the interest rate on liabilities rises to more than the interest rate on the bank's assets. Interest rate risk is the risk of declines of net interest income. Financial assets such as loans, receivables, and deposits generate revenues and costs that are interest rate driven. Any party who lends or borrows is subject to interest rate risk. Therefore, this study sought to answer the following questions:

How to optimize hedging practices in banks to hedge the exposure to interest rate risk and interest rate fluctuations? How can banks in Syria react when faced with stress market condition scenario?

Hedging has been much debated in recent years. Related to this study, Akhmedov F. et al., (2020)[1], found that financial engineering is a very important hedging practice in stress conditions, and that banks can use Credit Default Swap in these conditions to hedge positions against the exposure to the risk of default on an asset portfolio.

As derivatives are very common instruments used by banks (Bernadette Minton et al, 2009)[3], they received a great deal of attention in recent years. The use of derivatives in financial engineering continues to increase (Ashutosh Vashishtha and Statish Kumar, 2010)[2]. Therefore, the focus of this study is primarily on derivatives, and particularly on interest rate swaps, to provide banks with the hedging practices they need to a better approach to risk, a better hedging and, ultimately, a better banking industry. The aim is to optimize banks' hedging practices to accommodate the high cost of financial distress in stress conditions.

Hedging has been much debated in recent years. Related to this study, Fabozzi et al., (2002) [5] found that derivatives techniques have become so important in the world of risk management that a bank is at greater risk if it doesn't use derivatives techniques in managing risk and hedging position. They believe that banks as a total return payer are perfectly hedged as they have no risk position except for the counterparty risk of the total return receiver. Greenspan (2004)[6] found that derivatives have contributed to the development of a far more flexible, efficient, and hence resilient financial system than existed just a quarter-century ago, and concluded that derivatives and other complex financial instruments have enabled the largest and most sophisticated banks in their credit-granting role to divest themselves of much credit risk by passing it to institutions with far less leverage". Furthermore, Scott P. Mason (1995) [4] found that hedging is one of the basic ways to manage risk in banks. Robert Shiller (2003)[12] proposed the developing of more innovative financial instruments such as more innovative derivatives to deal with risks (Martin Neil and Douglas J. Elliott, 2013)[9]. Kenneth J. Arrow (1996) [8] points out that derivatives are very similar to insurance. Sagi Akron (2019) [11] stresses the growth of hedging instruments in emerging markets revives the debate regarding optimal hedging strategies. Roxana Angela Calistru (2012)[10] found that derivatives become tempting for those likely to take on more risk to make more money, meaning that the users of credit derivatives for protective purposes were outnumbered by the speculative ones.

Many challenges of risk management remain to be addressed. There is no distinguished research, neither in theory nor in practice, that fully succeeded to develop a sophisticated and a comprehensive risk management to manage risk and hedge position in stress market conditions. In Syria, current risk management practices remain unable to manage risk and hedge position in stress market conditions. This is why the topic of risk management and financial engineering is interesting and of a great significance.

This study sets itself apart from the existing literature on hedging by focusing on optimizing hedging in times of stress conditions in the case study of Banks in Syria. This study argues that current hedging practices can be improved to better withstand shocks in stress conditions. Therefore, the recommendations put forward in this study would result in a change to hedging practices in banks. The aim is to optimize these practices to accommodate the complexity of credit risk, the unpredictability of adverse events, and the severity of stress conditions. 


\section{METHODOLOGY}

Banks in Syria are experiencing their darkest days ever since they were established, but they are still trying to weather the current ongoing crisis in Syria. Though, risk management remain old-fashioned and out-of-date in banks in Syria. Risk avoidance, mitigation, and acceptance are the main types of risk management practices at banks in Syria. However, risk transfer is not yet a feature of the banking market. Therefore, there is a need for change. The society in Syria needs banks, banks need to change, and risk management needs to guide that change. Unfortunately, we found that current reform agenda and current initiatives in risk management are not enough and are unlikely to preserve banks in stress market conditions. Therefore, risk management needs to be upgraded across all areas of the banking industry in Syria to accommodate the complexity of risk, the unpredictability of adverse events, the severity of stress market conditions, and the sophistication of the contemporary banking industry. Improving risk management mechanisms is as vital as ever.

This study considers the case study of banks in Syria in optimizing hedging practices based on Interest Rate Swaps (IRS)s in order to optimize hedging in stress conditions, believing that the case study of these banks represents an overview into some empirical evidences of stress conditions under which banks need to hedge their interest rate risks and interest rate fluctuations. The story of banks in Syria offers many interesting insights into how banks can hedge their exposures to accommodate the complexity of risk, the unpredictability of adverse events, and the severity of stress conditions.

Questions on hedging are complex. There is a need to lay out some observations and analyses to answer those questions. Therefore, the Second section of this study provides empirical evidences and results of how can banks use interest rate swaps to optimize hedging in stress conditions, and addresses how the technicalities of this proposal would work in banks in Syria in stress conditions. Third section provides the conclusions.

\section{EMPIRICAL EVIDENCES AND RESULTS}

Banking in Syria has been through a long journey. The current ongoing crisis in Syria triggered substantial market volatility and an increased exposure to higher and more risks, and there is the perennial potential for markets to become more volatile. Prices, interest rates and exchange rates move sometimes in favour of the bank's liabilities, not in favour of the bank's assets. Moreover, banks in Syria finished the first year of the pandemic with serious risks. The current ongoing crisis left its mark on the banking system in Syria.

As the economy in Syria has contracted during the current ongoing crisis and the pandemic, the financial system witnessed an increase in the degree of financial intermediation. This is because banks have to absorb customers liquidity problem and debtors' financial needs during the crisis and pandemic. Banks in Syria have continued to grant loans at sustained pace in recent years, like they did prior to the current ongoing crisis. Even during the pandemic, banks in Syria have continued reviving up the engines of lending, covering customers' financing needs. This has been convoyed with higher risks. The upside is a higher financial intermediation creates the prerequisites for economic growth. The downside is that a higher financial intermediation means more risks. We are aware of the positive role that such an evolution of the degree of financial intermediation will have on reducing the level of poverty (Gabriela Folcut (2021))[7], the development as well as strengthening Syria's economic growth. To achieve this, the banking industry in Syria must be provided with a sophisticated risk management.

There is approximately one bank branch for every 41.000 people in Syria. In total, there are 20 banks with more than 450 branches in Syria. Out of 14 private banks in Syria, there are 3 Islamic banks. These banks are in place to provide financial products and services that are in compliance with Islamic law.

Still after the opening of the banking industry in Syria in 2004, the six State-owned banks remain major banks. Each one of these banks is specialized in a particular sector and for specific lending purpose.

At the most basic level, banks in Syria accept deposits, offer checking account services, make loans (business, personal, automobile and mortgage loans), extend lines of credit, offer automated teller machine services, and provide basic financial products such as certificates of deposit and safety deposit boxes. Broadly speaking, the services that banks in Syria provide are basically those shown as follows (table 1): 
Table 1: Banking Services in Banks in Syria

\begin{tabular}{|c|l|}
\hline Services & \multicolumn{1}{c|}{ Details } \\
\hline Custody of money & $\begin{array}{l}\text { Paper money can be convenient, but most people would rather have a bank look after } \\
\text { their "at hand" money. People leave their spare cash in their current account, rather than } \\
\text { in notes and bills. }\end{array}$ \\
\hline Payments services & $\begin{array}{l}\text { Some transactions in the economy need to be accompanied by a transfer of funds from } \\
\text { the buyer to the seller. Banks traditionally operate the payment system, whether through } \\
\text { cash handling, ATM networks, or electronic transfers. This is because payments are } \\
\text { closely tied to the provision of credit. }\end{array}$ \\
\hline Provision of credit & $\begin{array}{l}\text { Individuals and corporations need to borrow for a variety of reasons. This could be short- } \\
\text { term working capital to help them through a period where cash is tight, or a longer-term } \\
\text { capital investment (such as buying a house) that is converted into periodic repayments. } \\
\text { Banks are intermediaries between those with a need for credit and those with a need for } \\
\text { investment. }\end{array}$ \\
\hline $\begin{array}{c}\text { Investment } \\
\text { management }\end{array}$ & $\begin{array}{l}\text { Many individuals and corporations are cash-rich and/or need to put money by for future } \\
\text { needs, such as a pension. They need to put their money to work. This could be simply } \\
\text { by lending it to the bank, which is what a deposit account does. Or, it could be by } \\
\text { selecting a longer-term or riskier investment, such as buying shares. Most people use } \\
\text { banks as a source of their short-term financial investments (i.e. deposits). Long-term } \\
\text { investments are handled by banks and other types of companies, such as specialized asset } \\
\text { managers and insurance companies. }\end{array}$ \\
\hline $\begin{array}{c}\text { Market-making and } \\
\text { risk management }\end{array}$ & $\begin{array}{l}\text { Financial transactions in currencies, investments and risk management tools need to } \\
\text { match buyer and seller. Banks facilitate the matching process, either through their own } \\
\text { books or on an industry-wide marketplace. }\end{array}$ \\
\hline
\end{tabular}

\section{Source: by the Author}

In Syria, the Central Bank decides the interest rates. As those rates directly affect the credit market (loans), banks constantly try to predict the next interest rate moves, so they can adjust their own rates. A bad prediction on the movement of interest rates can cost millions. Interest rate fluctuations play a huge role in the profitability of a bank. Therefore, the proposed risk hedging mechanism can use Interest Rate Swaps (IRS)s to transform the nature of cash flows and the interest rate exposure of a portfolio or a particular asset or liability between two parties that agree to exchange periodic interest payments.

Loans are the predominant risk asset in banks in Syria (68.93\% of total assets). Therefore, banking in Syria become a concentrated domestic industry in recent years $(90.10 \%$ of total deposits are in local currency, and there is a high positive correlation between loans and assets 93.66\%). This intense focus led to banks building large positions in lending business. However, strict underwriting standards, high collateral requirements, high rates on loans, and tightened credit conditions during the current ongoing crisis in Syria are the reasons behind the decline in loans in recent years.

However, a high Loans to deposits ratio in banks in Syria (118.22\% on average in recent years) means that these banks tend to make loans with a volume that exceeds the deposits they have on their balance sheets, and that they tend to be vulnerable to any sudden adverse changes in deposit base (such as a bank run) and may not have enough liquidity to cover any unforeseen fund requirements during the current ongoing crisis.

In terms of loanable funds, we found that deposits are the most common, and very often the cheapest, source of loanable funds for banks in Syria (66.73\% of total assets on average). Therefore, a potential bank run would have a severe consequence on the financial health and stability of banks. Deposits give a sense of how much lending a bank can do due to the high positive correlation coefficient between loans and deposits in recent years (88.35\%). Deposit growth in banks in Syria has an order 2 polynomial trendline due to the bank run $26.36 \%$ in 2012 as a valley.

Although it is better than the other way around, the risks accompanied with high deposit growth need to be managed and hedged under a sophisticated risk management. Otherwise, problems can arise if deposit growth races ahead of risk management capabilities. Therefore, it is important to consider the costs and uses of those funds. Accumulating deposits in banks, particularly at higher rates, are actually bad for earnings if the bank cannot profitably deploy those funds compared to what the bank is investing in making loans. 
Given the huge accumulated losses in banks in Syria (SYP66.42bn in recent years), their insolvency, and the bank run in two banks in $2016(21.36 \%$ and $17.94 \%)$, we found that the current ongoing crisis in Syria increased investors' fears, and put banks financial health under threat, and the market is becoming increasingly nervous. Moreover, given the high average loans to deposits ratio (LTD) in banks in Syria (118.22\% in recent years), their high average loans to assets ratio (68.93\%), and their high positive correlation between loans and assets (93.66\%), we found that banks' lending focus in Syria is intense. These banks are very active in some of the riskiest areas of banking. Loans are the predominant risk asset for banks in Syria (68.93\% of total assets). This means that banks' growth in Syria (asset growth reached $31.64 \%$ in recent years) was driven by an expanding risk taking, excessive exposure, and dominance of lending business. As a consequence, banking in Syria become a highly concentrated industry and reliant upon the health not only of the financial system but also of the lending market. In our opinion, the performance of lending market was essential to the overall performance of banks and also survival. If the lending business turns, banks will bound to suffer losses. Such concentration made financial products even more risky. Unfortunately, it seems that banks in Syria remained confident in their business model and did not seem to be overly concerned by the risks they run. These excessive exposures led to a rapid and massive build-up of risk during the current ongoing crisis and, ultimately, losses. These losses reflect the fragility of the financial profile, the deteriorating risk profile, and the deficiency of risk management at banks in Syria. These issues spread like a contagion from bank to bank.

The seeds of a banking crisis in Syria are being sown today already. Beyond the specific case of any bank, risk management at banks in Syria was by no mean complete and by no mean perfect. Its current practices exposed multiple areas of weakness.

We believe that if banks in Syria have had a sophisticated risk management, it is likely that many of the calamities of the current ongoing crisis on banks in Syria could have been avoided or at least mitigated. Many of these calamities were the result of the flaws in risk management that was riskier in practice than anyone has imagined.

In summary, we found that banks in Syria have limited options to manage the risks they are running. The ability of banks to withstand shocks has proven to be extremely limited. We have found that banks in Syria are not resilient enough to sustain periods of stress market conditions. The current ongoing crisis has exposed many flaws in risk management at banks, and massive problems in their approach to risk.

After setting the scene with a look at the banking book, loan portfolio, and deposit base in banks in Syria in recent years, we found that ever since the current ongoing crisis in Syria started to unfold in 2011, banks have been under decreasing net interest margins due to market volatility. This volatility forced banks' net interest spreads to decrease. For instance, if a bank in Syria has the opportunity to borrow some money in floating interest rate at an attractive amount, and it would cost a lot more to borrow the funds in fixed interest rate, the bank faces the risk of a fluctuation in the floating interest rate which will impact the repayments it has to make. An increase in floating interest rate will increase the amount of debt to be repaid, potentially causing financial problems. The proposed risk hedging mechanism to hedge positions against the exposure of banks to fluctuations in interest rate would function as follows:

The bank agrees an interest rate swap with a swap services provider. Such swap fixes the schedule of payments that the bank must make.

At each date when interest and principal are due, the bank receives floating interest rate payments and makes fixed interest rate payments, as per the agreed derivative schedule.

This way, the proposed risk hedging mechanism has proven remarkably successful to hedge positions to the exposure of interest rate risk by transforming the floating interest rate borrowing into fixed interest rate borrowing based on Interest Rate Swaps. For the bank, the end result of using the proposed risk hedging mechanism is as if it had borrowed in the fixed interest rate all along. Accordingly, the bank will not be exposed to fluctuations in interest rates at all. Figure 1 presents a visual model diagram of the proposed risk hedging mechanism to hedge position against the exposure of banks to fluctuations in interest rate via an Interest Rate Swap Contract. 


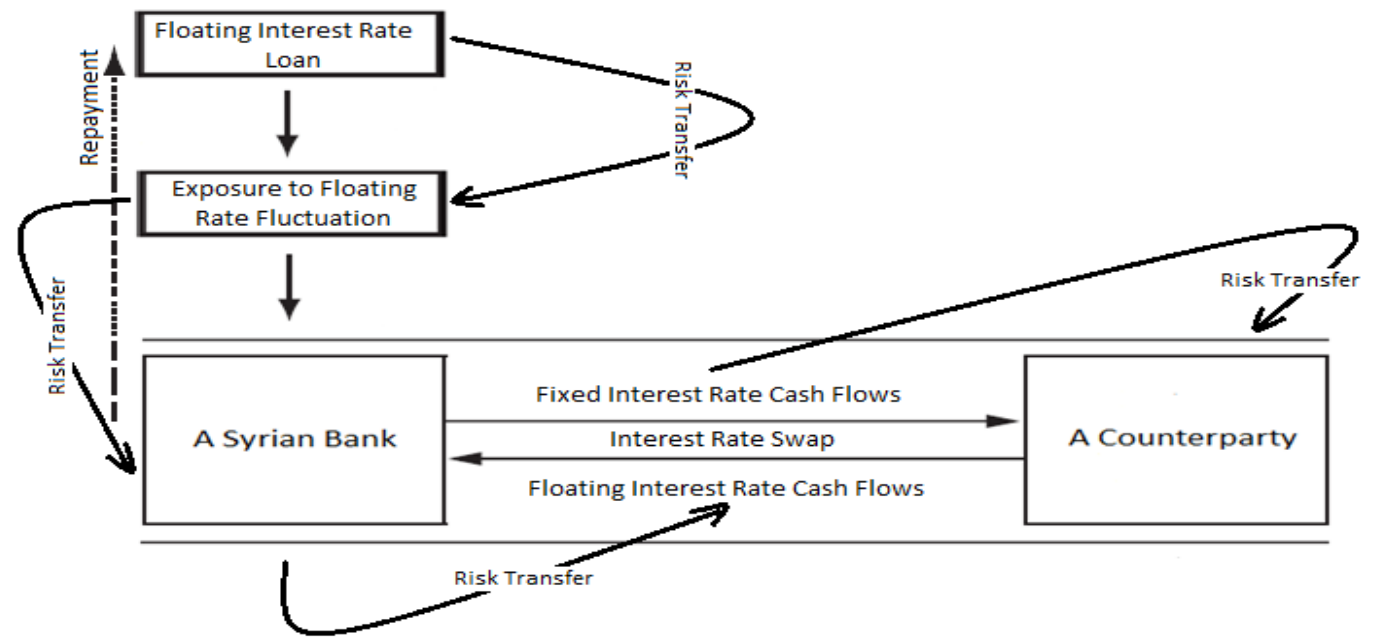

Figure 1 The Proposed Risk Hedging Mechanism to Hedge Positions Against the Exposure of Banks to Fluctuations in Interest Rate Via an Interest Rate Swap Contract

Source: by the author

In another example, the proposed risk hedging mechanism can be used to overcome the asset-liability mismatch in banks and hedge interest rate risk and interest rate fluctuations. For instance, Bank A in Syria has a floating rate asset (such as LIBOR+3\%) funded with fixed rate liability of $12 \%$, and on the other hand, Bank B in Syria has fixed rate assets earning 17\%, funded with floating rate liability (LIBOR+1\%). In this case, both banks have an exposure to interest rate risk and interest rate fluctuations. Bank A will suffer if the interest rate falls as it will receive less on its assets. And Bank B will suffer if interest rate rises as it will have to pay more on its liabilities. Therefore, to overcome such exposure, both banks can use the proposed risk hedging mechanism to enter into an interest rate swap transaction to hedge interest rate risk and interest rate fluctuations wherein:

Bank A pays Bank B floating interest rate (LIBOR) on the notional principal.

Bank B pays Bank A fixed interest rate (14\%) on the same notional principal.

With Interest Rate Swaps, the proposed risk hedging mechanism would ensure that both banks hedge their exposure to interest rate risk and interest risk fluctuations. Therefore, Interest Rate Swaps would enable banks in Syria that have fixed rate liabilities to capitalize on floating interest rate swap, and vice versa. Chart 1 illustrates the assets that can be hedged against the exposure to interest rate risk using the proposed risk hedging mechanism in banks in Syria in 2016.

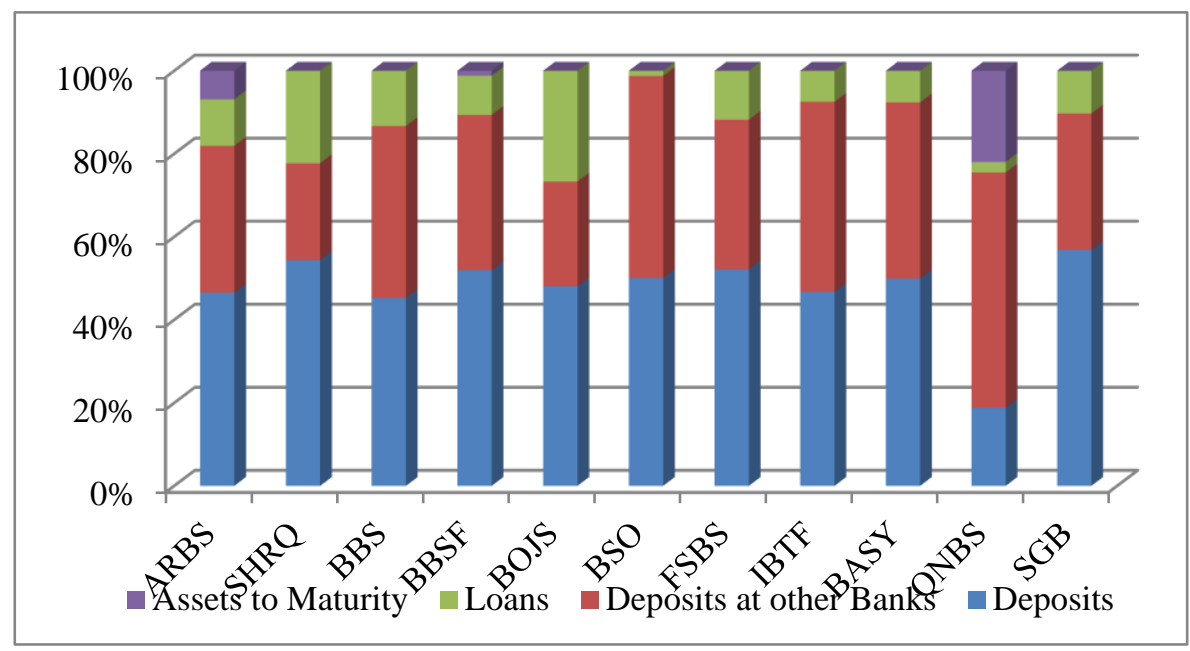

Chart 1 Assets That Can Be Hedged Against the Exposure to Interest Rate Risk Using the Proposed Risk Hedging Mechanism in Banks in Syria in 2016 (SYP)

Source: by the author based on banks' financial reports 
Based on chart1, the proposed risk hedging mechanism would enable banks in Syria to hedge a position of SYP1673bn, or $75.14 \%$ of total assets, and $69.83 \%$ of total liabilities, against the exposure to interest rate risk and interest rate fluctuations based on Interest Rate Swaps. Figure 2 illustrates the assets that can be hedged against various exposures using the proposed risk hedging mechanism in banks in Syria in 2016.

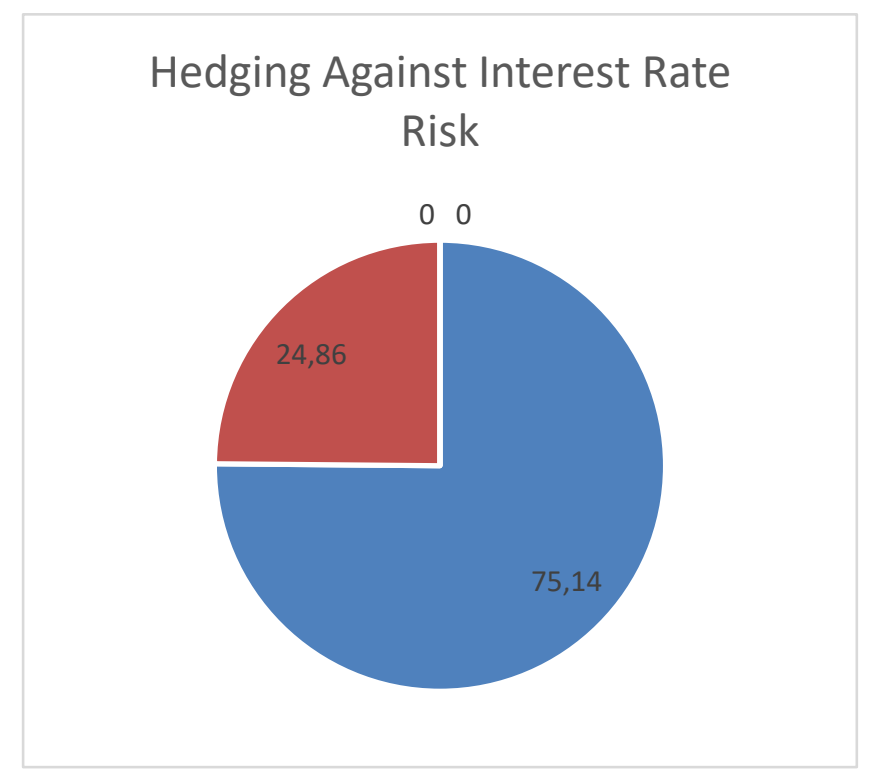

$75.14 \%$ of total assets in banks in Syria can be hedged against the exposure to interest rate risk based on our proposed risk hedging mechanism

Figure 2 Assets That Can Be Hedged Against Interest Rate Exposures Using the Proposed Risk Hedging Mechanism in Banks in Syria in 2016

Source: by the Author based on Banks' Financial Reports

Syrian authorities, the private sector, and banks should be able to pace their steps using the proposed hedging model to identify solutions to push for a better banking industry and a better risk management.

\section{CONCLUSION}

Risk management is a large topic. Its functions, mechanisms and models cannot be fully addressed within the scope of one research. Nevertheless, this research has been written to reflect on the main points related to make a significant amount of progress to address the challenges in risk management at banks. The case study of banks in Syria represents an overview into some empirical evidences of the recent challenges of risk management at banks around the world. These evidences provide a reasonably good diagnostic of the challenges that banks face and a few hints as to what better risk management might be and what better risk management is certainly not.

Financial Engineering has been addressed in this study as a very important hedging practice to be in use by banks in stress conditions. Banks can use Interest Rate Swaps in stress market conditions to hedge positions against the exposure to interest rate risk of an asset portfolio such as a portfolio of loans. Therefore, Swaps have been addressed as part of the solution to interest rate risks. They can make banks more resilient to the challenges they encounter in stress conditions such as the pandemic, the current ongoing crisis in Syria or even the domino effect among banks caused by the distortions in the economy.

The analysis of the banking system in Syria in terms of financial indicators showed that banks are not resilient enough. A worse stress condition may have negative effects. It all depends on the resilience of the banking system but also on financial instruments in use to hedge various positions and exposures. We addressed our optimism that we will witness a recovery of Syria's banks' positions if risk were managed using innovative financial engineering so that the likelihood of stress conditions will be lower.

Banks in Syria might be able to survive stress market conditions in the short-term, but their solvency can fail them in the end in the long-term. More technically, given the huge accumulated losses in banks in 
Syria and the high average loans to deposits ratio (118.22\% on average), we found that banking in Syria has evolved into a risky and concentrated industry during the current ongoing crisis. The activities of banks have expanded in recent years (average deposit growth $24 \%$ and average asset growth $31.64 \%$ in recent years) so did their exposure. Banks' growth in Syria was driven by an expanding exposure, and therefore expanding risk (68.93\% loans to assets and 66.73\% deposits to assets in 2016).

Risks are present alongside opportunities. Interest Rate Swaps are one of these opportunities. The evolution of the banking system, which is a mirror of the economy, is dependent on financially engineered instruments, such as Swaps to hedge the exposures to risk in the contemporary stress conditions.

With the hedging proposal of this study, banks would be able to hedge their positions in stress conditions to the exposure to interest rate fluctuations via Interest Rate Swap.

As banks in Syria have been battered by the storms of the current ongoing crisis in Syria, the hedging proposal of this study has proven to be able to hedge $75.14 \%$ of total assets to the exposure to interest rate risk and interest rate fluctuations. These positions remain exposed to high risks during the current ongoing crisis in Syria due to the lack of a sophisticated hedging in banks in Syria.

Finally, financial engineering needs a broader and fuller public debate and academic research on the restructurings that need to be implemented. This study has attempted to provide a key to enable and inform that debate. However, shedding light on optimizing hedging to better withstand shocks in stress conditions opens up new boxes of intriguing questions. How to hedge the exposure of banks to fluctuations in foreign exchange rates? What are the risks and disadvantages of using derivatives in hedging? We refer these to further research. 


\section{REFERENCES}

[1] Akhmedov F. N., Zeitoun M. S., Al Humssi A. (2020). Financial Engineering to Optimize Hedging in Banks Based on Derivatives to Better Withstand Stress Conditions the Case of Banks in Syria. Filodiritto Editore -Proceedings of the International Scientific and Practical Conference: DIGITAL FINANCE 2020 (DF2020) Moscow pp. 67 - 72.

[2] Vashishtha A., Kumar S. (2010), Development of Financial Derivatives Market in India- A Case Study, International Research Journal of Finance and Economics. https://casi.sas.upenn.edu/sites/default/files/iit/Derivatives\%20-\%20Vashishtha.pdf

[3] Minton B., Stulz R. \& Williamson R. (2009). "How Much Do Banks Use Credit Derivatives to Hedge Loans?" Journal of Financial Services Research, Springer, vol. 35(1), pp.1-31., February URL: http://citeseerx.ist.psu.edu/viewdoc/download?doi=10.1.1.121.886\&rep=rep1\&type=pdf

[4] Dwight B. Crane et al., The Global Financial System: A Functional Perspective (Harvard Business School, 1995). Chapter 5 is "The Allocation of Risk", by Scott Mason. Leading college textbooks covering this material are Zvi Bodie, Robert C. Merton and David L. Cleeton, Financial Economics, second edition 2009 and Frederic S. Mishkin, Economics of Money, Banking and Financial Economics, tenth edition 2012.

[5] Frank J. Fabozzi, Francis Gupta, Harry M. Markowitz (2002). The Legacy of Modern Portfolio Theory The Journal of Investing, 11 (3) pp. 7-22; DOI: https://doi.org/10.3905/joi.2002.319510

[6] Greenspan, A., (2004). Economic flexibility, speech to HM Treasury Enterprise Conference, London, U.K. URL: https://www.federalreserve.gov/boarddocs/speeches/2004/20040126/default.htm

[7] Folcut G. (2021). The increase in non-performing loans - one of the risks of the banking system this year. Interview recorded by Emilia Olescu 15 Mar 2021. The increase in nonperforming loans - one of the risks of the banking system this year - 15.03.2021| BURSA.RO

[8] Arrow, Kenneth J, (1996). "The Theory of Risk-Bearing: Small and Great Risks," Journal of Risk and Uncertainty, Springer, vol. 12(2-3), pages pp. 103-11.

[9] Neil MB, Douglas EJ. (2013). The role of finance in the economy: implications for structural reform of the financial sector. http://www.brookings.edu/ /media/research/files/papers/2013/07/11-finance-role-ineconomy-baily-elliott/11-finance-role-in-economy-baily-elliott.pdf

[10] Calistru R.A. (2012). The credit derivatives market a threat to financial stability? 8th International Strategic Management Conference. Procedia - Social and Behavioral Sciences 58 ( 2012 ) pp. 552 - 559. doi: https://doi.org/10.1016/j.sbspro.2012.09.1032

[11] Akron S. (2019). The optimal derivative-based corporate hedging strategies under equitylinked managerial compensation Emerging Markets Review Volume 41, December 2019, 100631 https://doi.org/10.1016/j.ememar.2019.100631

[12] Shiller, Robert, J. (2003). "From Efficient Markets Theory to Behavioral Finance ." Journal of Economic Perspectives, 17 (1): 83-104. DOI: https://doi.org/10.1257/089533003321164967

\section{Article history:}

Received 14 April 2021

Accepted 10 July 2021 